\title{
The Law Merchant and California Decisions
}

The characteristics of mechanical jurisprudence have been defined to consist in the tendency "to regard artificiality in law as an end, to hold science something to be pursued for its own sake; to forget in this pursuit the purpose of law and hence of scientific law, and to judge rules and doctrines by their conformity to a supposed science and not by the results to which they lead." ${ }^{\prime}$ Nowhere has the struggle for freedom from the fetters of an artificial system of law been fiercer than in negotiable instruments, and nowhere has the struggle to get the rule that best accords with and gives effect to sound business practice, been less successful than in California.

England before and for a long time after the Norman Conquest, was not a commercial country. Contractual relations did not play a prominent part in daily life, and the law of contract, therefore, existed only in a rudimentary stage. It took centuries to develop the modern theory of a contract by simple agreement between the parties. ${ }^{2}$ Commercial growth required not only the enforcement of business agreements, but also the assignability of the contract created. This notion of assignability also grew slowly. The idea that " $A$ ", who had become bound to " $B$ ", could, without his own consent, become bound to "C", was a difficult one to grasp. The history of the severity of execution on delinquent debtors must have left its mark as a part of the race experience. "A" might be willing to take the risk of default in dealing with " $\mathrm{B}$ ", but not in dealing with " $\mathrm{C}$ ". ${ }^{3}$ There were also technical difficulties in connection with the form that such an assignment should take. There was nothing to be visibly and openly transferred, until it became common to put contracts in the form of a document and to regard the contract as embodied in the document. 4 Commercial development, however, demanded the assignability of contracts. It took a court of equity to work out the process in England, aided perhaps by the fact that the early

1 Roscoe Pound, 8 Col. Law Rev. 608.

2 Pollock and Maitland, History of Eng. Law, vol. II, 184.

3 Loyd, 62 Univ. of $\mathrm{Pa}$. Law Rev. 354.

4 Pollock and Maitland, History of Eng. Law, vol. II, p. 226; Jenk's, Select Essays in Anglo-American History, vol. III, p. 65. 
English law operated very favorably to debtors, - but the method is unimportant,-the result is that assignability of contract is today the rule. The obligor can always protect himself, if he wishes, by expressly providing that the contract shall not be assigned and by using apt words to accomplish that purpose.

The merchants in England, inany of them foreigners, with whom contract was a part of their daily business, worked out independently the assignability of contracts, and, for certain instruments, an assignability free from equities which the obligor could have set up against the assignor and free from infirmities in the title of intermediate holders. These two characteristics are commonly called "negotiability". Negotiability, however, has never been extended to ordinary contracts, and this is in accord with modern ideas. An ordinary contract is assignable, not negotiable. Commercial paper, like bills and notes, however, is an instrument of credit, performing in part the functions of money, and must, therefore, like money, pass freely from hand to hand. The intention of the parties is that the instrument shall have the additional value which comes from the bona-fide purchaser taking free and clear of equities. An ordinary contract, however, is made to be performed, not assigned. Assignment is not usually contemplated, and it is, therefore, better to require the assignee to find out, at his peril, whether the obligor has a defense, than to facilitate dishonesty by permitting one who has obtained a contract by fraud to assign it free from such defenses. The business man who buys an ordinary contract knows that he is getting nothing more than the right of his assignor. It is a question not of principle, but of policy, like the corresponding law of chattels. In London the law of market overt prevails. A purchaser from a shop gets title whether the shopkeeper owned the goods or not. ${ }^{6}$ In Germany a purchaser at public auction is protected. ${ }^{7}$ The French law also favors the purchaser. ${ }^{8}$ In the United States it is considered better that the honest purchaser should occasionally lose the property than that theft should be encouraged by affording a ready market for stolen goods.

While, however, the law is satisfactorily settled on the basis

5 Dollar v. Internatl. Banking Corp. (1909), 10 Cal. App. 83, 101 Pac. 34.

6 Ency. of the Laws of Eng., vol. IX, p. 3; Hargreave v. Spink, [1892] I. Q. B. 25; see Clayton v. I,eRoy, [1911] 2 K. B. 1031.

7 German Civ. Code, \$\$ 929-935.

8 French Civ. Code, $\$ \S 2279-2280$. 
that an ordinary chose in action is assigned subject to equities and defects in title, is there any reason why the parties cannot expressly stipulate for negotiability; why in a contract whereby " $A$ " agrees to deliver to " $\mathrm{B}$ " or bearer 1000 tons of iron, it can not be provided-

I. That if the contract shall be assigned or come into the possession of " $C$ " honestly, " $A$ " will set up no defenses that he might have asserted against " $B$ ",

2. If no suspicious circumstances present themselves " $A$ " may discharge his contract by delivering the iron to the party presenting the document?

That this first stipulation can be made and is binding is generally conceded. The validity of the second has been denied by no less an authority than Sir Frederick Pollock.

"The assignee of a contract is under two inconveniences. The first is that he inay be met with any defence which would have been good against his assignor. This, we have seen, may to a considerable extent if not altogether be obviated by the agreement of the original contracting parties.

"The second is that he must prove his own title and that of the intermediate assignees, if any; and for this purpose he must inquire into the title of his immediate assignor. This can be in part, but only in part, provided against by agreement of the parties. It is quite competent for them to stipulate that as between themselves payment to the holder of a particular document shall be a good discharge; but such a stipulation will neither affect the rights of internediate assignees nor enable the holder to compel payment without proving his title. Parties cannot set up a market overt for contractual rights."

Why should not intermediate assignees be bound by the stipulation that performance to the holder shall discharge the contract? An assignee does not have to take the above contract unless he wants to. If he does accept it, it contains on its face a limitation on his right to enforce it, to-wit: that if he loses it or allows it to come into the hands of a bona fide purchaser, his rights are gone. By the very purchase of the instrument with this provision in it, the assignee makes himself a party thereto. Precedent can be found in support of Sir Frederick Pollock's view, ${ }^{10}$ but it is

- Pollock on Contracts, *228.

10 Pollock on Contracts, $* 231$. 
precedent based on the law of an age when contracts could not be assigned at all. Modern rational law has removed the last restrictions on the right to make contracts not contrary to public policy. What rule of public policy is there standing in the way of the court enforcing the above contract exactly as the parties have made it? The opinion to the contrary is inconsistent with modern authority and sound principle. The California Code Commissioners recognized the rationality of the principle of negotiability by agreement. ${ }^{x x}$ It is a special application of a general principle.

"Save when the interests of the public at large demand a different rule, the autonomy of consenting parties prevails over the legislative will of the state. So far as may be, the state leaves the rule of right to be declared and constituted by the agreement of those concerned with it. So far as possible, it contents itself with executing the rules which its subjects have made for themselves. And in so doing it acts wisely."12

If we once admit that it is competent for parties by express agreement to provide that a contract shall pass freely from hand to hand so that a bona fide holder shall take free and clear of personal defenses of the obligor and from infirmities in the title of all prior holders, the question of the so-called negotiability of any particular instrument is comparatively easy of solution. It is merely a question of whether the law or custom has annexed by implication those terms which the parties could have incorporated by express agreenent. A consideration of the instruments to which such terms are impliedly annexed, requires a study of the so-called law merchant. As has been heretofore pointed out, the restrictions on assignability were incompatible with commercial development. When coinmerce became general over all England and was no longer the exclusive concern of a particular class at fairs and staple towns, the law as developed by the merchants became part of the general law of England. Unfortunately, with the decay of the fairs and the staple towns, their courts went with them, and, as few records seem to have been kept by these courts, and some of those records have been destroyed, the ad-

1 Cal. Civ. Code, $\$ 3093$. "Note-An obligation to pay money and to do anything in addition, is not negotiable.-Austin v. Burns, 16 Barb., p. 643; Martin v. Chauntry, 2 Str., p. 171. But see Sec. 3090. It has been said that an instrument cannot be made negotiable by calling it so on its face. But it may be worthy of consideration whether parties should not be allowed by express words to bring any contract within the rules of negotiable paper."

12 Salmond, Jurisprudence, $\S 123$. 
ministration of the law merchant came into the hands of the common law courts, receiving at times anything but sympathetic treatment. ${ }^{13}$ It is, of course, well known that Lord Holt refused to recognize promissory notes as negotiable instruments, declaring that it was the opinionativeness of Lombard Street that led them to declare on notes as such. ${ }^{14}$ The opinionativeness, however, was Lord Holt's. He was wrong, as a matter of law, and Parliament set him right as a matter of policy. ${ }^{15}$ It was Lord Mansfield who really made the custom of merchants the law of England, but the conflict has left its mark in modern law. This manifests itself in the refusal to recognize new forms of negotiable instruments, -an attitude as sensible as the refusal to recognize a chrysanthemum as a flower because it is not a rose or a violet or known to the English garden of the eighteenth century. And even where, as in England, new forms of negotiable instruments are recognized, slight variations from the conventional forms of the old instruments render them non-negotiable. ${ }^{16}$ By the attitude of one class of judges, the principle of negotiability is an exotic in the English law, to be followed only so far as precedent requires. Lord Mansfield's innovations are accepted, but no extension of the underlying principle is permitted. This is the mechanical theory. The other class of judges regard the law merchant as a part of the law of England as truly as equity, ecclesiastical law, admiralty, or any other system that grew up outside the common law courts. It was the misfortune of this branch of law that its special courts did not survive. Under that view of the law which formulates principles to suit business needs, negotiability is a principle of general application, as a part of any rational system of freedom of contract to be applied,-

I. Wherever the parties agree that it should be; and

2. Wherever by general custom proved in the usual way, the particular instrument is so regarded by business men.

This would seem to be the prevailing view in England and the United States. ${ }^{17}$ In California, unfortunately, the law follows

13 Selden Society Publications, vol. XXIII, Introduction.

14 Clerke v. Martin, 2 Ld. Raym. 757.

15 Select Essays on Anglo-American Legal History, vol. III, pp. 89-93; see opinion by Cranch, J., 1 Cranch 367.

${ }_{16}$ Chalmers, Bills of Exchange, 6th ed., \$ 83, provision for whole to become due on payment of one installment seems to render note non-negotiable.

${ }_{17}$ The reasoning in support of this view and its application to particular documents is set forth in Ewart on Estoppel, see especially 
Holt and not Mansfield. The principles of negotiability were taken from the few instruments in common use in the early part of the nineteenth century. These principles were prematurely and narrowly codified, thus further restricting expansion; and the judicial construction of the code has further confined the law merchant to its ancient bounds.

It may be contended that the mechanical following of precedent produces certainty. Never could there be a greater delusion. Follow blind precedent for a few generations and the law bears the same relation to justice, common sense and business convenience as if the court applied the supernatural tests of ordeal by fire and water or tossed up a coin. Judges constantly revolt from the application of an imperfectly generalized rule to changed conditions, with the inevitable consequence that the reign of blind precedent means injustice and uncertainty.

The California law of negotiable instruments affords numerous illustrations. It has been held, ${ }^{18}$ contrary to the great weight of authority elsewhere, ${ }^{10}$ that the inclusion of a provision for an attorney's fee in an instrument otherwise negotiable renders it nonnegotiable. As the provision for attorney's fees takes effect only after maturity, when the note has lost a portion of its negotiable character, it is difficult to say why such a provision should make any difference. The California cases admit that there is a conflict in the decisions on this point, but hold that the provisions of the code preclude any other ruling. It is submitted, however, that the sections relied on were intended to embody the well established rule that the instrument must be payable unconditionally, that is, not made to depend on an uncertain act, such as the building of a house in the future; and were not intended to apply

Chap. XXIV, and the cases of Re Agra \& Masterman's Bank, [1867] L. R. 2 Ch. 397, 36 L. J. Ch. 222, and Merchant Banking Co. v. Phoenix Bessemer Stee1 Co., [1877] 5 Ch. D. 205, 46 I. J. Ch. 418.

18 Chase v. Whitmore (1886), 68 Cal. 545, 9 Pac. 942; Adams v. Seaman (1890), 82 Cal. 636, 23 Pac. 53; Prescott v. Grady (1891), 91 Cal. 518, 27 Pac. 755; First Nat'1 Bank v. Babcock (1892), 94 Cal. 96, 29 Pac. 415, 28 Am. St. Rep. 94; First Nat'1 Bank v. Falkenhan (1892), 94 Cal. 141, 29 Pac. 866; Haber v. Brown (1894), 101 Cal. 445, 35 Pac. 1035; Kendall v. Parker (1894), $103 \mathrm{Cal}$. 319, 37 Pac. 401, 42 Ám. St. Rep. 117; Alexander v. McDow (1895), 108 'Cal. 25, 41 Pac. 24; Mason v. Iuce (1897), 116 Cal. 232, 48 Pac. 66; Findlay v. Pott (1901), 131 Cal. 385, 63 Pac. 694; Meyer v. Weber (1901), 133 Cal. 681, 65 Pac. 1110; National Hardware Co. v. Sherwood (1913), $165 \mathrm{Cal}$. 1, 130 Pac. 881 .

19 Daniel on Negotiable Instruments, 6th ed., \$§ 61-62 a. 
to the collateral stipulations inserted to make the unconditional payment more secure. ${ }^{20}$

As Parliament overruled Lord Holt, so did the California legislature in I905 recall the decision as to attorney's fees and costs of suit. ${ }^{21}$ Unfortunately, the amendment covered none of the other legislative and judicial mistakes in regard to other provisions commonly found in negotiable instruments and to which the same reasoning applies, such as costs of collection, ${ }^{22}$ exchange, ${ }^{23}$ waivers of exemptions, of notice and diligence in presentation and of the statute of limitations, ${ }^{24}$ power to confess judgment after maturity, ${ }^{25}$ additional interest after maturity ${ }^{26}$ and option of the holder to extend the time of payment. ${ }^{27}$ It has been

20 "A negotiable instrument must be made payable in money only and without any condition not certain of fulfillment." (Cal. Civ. Code, $\S 3088$.) "A negotiable instrument may contain a pledge of collateral security, with authority to dispose theerof." (Id., § 3092.) "A negotiable instrument must not contain any other contract than such as is specified in this article." (Id., $\S 3093$.)

21 Cal. Civ. Code, $\S 3088$, amended by Stats. 1905, p. 96, by adding the following exception: "except that it may provide for the payment of attorneys' fees and costs of suit, in case suit be brought thereon to compel the payment thereof."

22 Daniel, § 61.

23 Daniel, $\$ 54,54 a$.

2t Daniel, \& 61 .

25 Danie1, § 61; 14 Col. Law Rev. 90.

267 Cyc. 595.

27 Daniel, § 47. The promissory note involved in the action of Navajo County Bank v. Dolson (1912), 163 Cal. 485, 126 Pac. 153, was delivered in Arizona, and under the Arizona law was held negotiable, although it waived grace and protest, homestead and exemption laws, provided for a ten per cent additional payment if placed in the hands of an attorney for collection; and provided, further, that after maturity, the note might be extended from time to time, without affecting the liability of the other makers. This latter provision was construed to give the option to the holder. Apparently, even this provision would render the note non-negotiable in California, as the court says: "It is to be noted that there does not appear to be contained in the Arizona law any provision similar to our section 3093 of the Civil Code, declaring that a negotiable instrument must not contain any other contract than such as is specified in the article relating to such instrument." In a case where the option was given to the maker to pay before maturity, Judge Cooley said: "Notes like this are common in commercial transactions, and we are not aware that their negotiable quality is ever questioned in business dealings. It ought not to be questioned for the sake of any distinction that does not rest upon sound reason, and we can discover no sound reason for the distinction here insisted on." Mattison v. Marks (1875), 31 Mich. 421. 
held, ${ }^{28}$ contrary to the weight of authority elsewhere, ${ }^{29}$ that a provision for accelerated maturity, to-wit: that on the default in the payment of the interest due before the maturity of the principal, the holder has the optional right to declare the principal due immediately, renders a note non-negotiable. The decision to that effect in National Hardware Company v. Sherwood purports to rest for this point on Meyer v. Weber, ${ }^{30}$ but Meyer v. Weber was decided on the ground that the note included attorneys' fees, and on the further ground that the note was secured by mortgage. The accelerated inaturity provision was not made a ground of decision but was only incidentally referred to, to show that the inortgage must be construed with the note, as otherwise no action could have been brought on the note, the provision for accelerated maturity being contained in the mortgage and not in the note. Installment notes giving an option to the holder to declare the whole due on default in one installment are also non-negotiable in California. ${ }^{31}$

The fact that the consideration for the instrument is to be performed in the future has been held to make the note non-negotiable in the hands of a purchaser knowing that fact, even though the purchase is made before the failure of the consideration..$^{32}$ The decision to this effect was reversed by the Supreme Court on a ground that will be considered later. ${ }^{33}$ As most bills of exchange and many promissory notes are given for executory considerations, and that fact is frequently known to the purchaser, the decision of the District Court of Appeal is surprising and contrary to the weight of authority. ${ }^{3 t}$ It is intended by the parties that the instrument shall be negotiable. The negotiable forn is used in order that

28 National Hardware Co. v. Sherwood (1913), 165 Cal. 1, 130 Pac. 881; Smiley v. Watson (1914), it Cal App. Dec. 697, 138 Pac. 367. This latter case is not inconsistent with Kinsel v. Ballou (1907), 151 Cal. 754,91 Pac. 620 , as suggested in 12 Mich. Law Rev. 496. The action in Kinsel v. Ballou was by the holder against his immediate indorser; no question of the rights of a purchaser for value arose.

29 Daniel, \& 48 .

30 (1901), 133 Cal. 681, 65 Pac. 1110.

$31 \mathrm{Hall}$ v. Wells (Apr. 2, 1914), 18 Cal. App. Dec. 465.

32 Flood v. Petry (1912), 15 Cal. App. Dec. 332. The court said: "Where a third party becomes the purchaser or endorsee of an unmatured promissory note with notice that the consideration is, as is the case here, contingent in its character and which is therefore liable to fail before it becomes an unconditional consideration, the defense of failure of consideration would be equally as good against such note in the hands of the endorsee or purchaser, as it would be in the hands of the payee."

${ }_{33}$ Flood v. Petry (1913), 165 Cal. 309, 132 Pac. 256.

347 Cyc. 948. 
the payee may be able to raise money on it immediately. In other words, it is intended as a part payment in advance. In the case of Russ Lumber and Mill Co. v. Muscupiabe Land and Water Co., ${ }^{35}$ relied on by the District Court of Appeal, it was alleged that the plaintiff, at the time of the transfer to him, knew that the consideration would not be performed.

Under the Negotiable Instruments Act the decisions on practically all the above points are in accord with the weight of authority in holding the instrument negotiable. In California, however, where there is no express decision, the instrument would probably be held non-negotiable.

It has been held, ${ }^{36}$ contrary to the prevailmg rule, ${ }^{37}$ that a note secured by mortgage is non-negotiable. This is rested in part on section 3092 of the Civil Code which provides that a negotiable instrument "may contain a pledge of collateral security with authority to dispose thereof"; and section 3093 which provides that a negotiable instrument "must not contain any other contract than such as is specified in this article." The decision is also based on section 726 of the Code of Civil Procedure, which prevents an independent action from being brought on the note and limits the right of the holder to a foreclosure of the security and a deficiency judgment. In most jurisdictions the holder of the note may waive his mortgage security and sue on the note. The negotiability of the note, therefore, so far from being impaired, is increased; and where there are stipulations in the mortgage, such as for the payment of taxes, msurance, and where there are other covenants inconsistent with negotiability, the tendency of the court is to construe separately the note and mortgage in order to preserve the negotiable character of the note. ${ }^{38}$ In California, on the other hand, a promise to pay simply the deficiency arising after a judicial sale of the property, is something very different from the usual promissory note. It is a question whether a mortgage is looked

35 (1898), 120 Cal. 521, 52 Pac. 995, 65 Am. St. Rep. 186.

36 Meyer v. Weber (1901), 133 Cal. 681, 65 Pac. 1110; Briggs v. Crawford (1912), 162 Cal. 124, 121 Pac. 381; Helmer v. Parsons (1912), 18 Cal. App. 450, 123 Pac. 356; Mentry. v. Broadway Bank etc. Co. (1912), $20 \mathrm{Cal}$. App. 388, 129 Pac. 470; National Hardware Co. v. Sherwood (1913), 165 Cal. 1, 130 Pac. 881 (overruling McDonald v. Randall (1903); 139 Cal. 246, 72 Pac. 997); Taylor v. Jones (1913), 165 Cal. 108, 131 Pac. 114; Metropolis Trust \& Savings Bank v. Monnier (1913), 46 Cal. Dec. 512 (rehearing pending).

37 Daniel, §§ 834, 834a.

38 Daniel, \$ 53 . 
upon by business men merely as collateral to facilitate the transfer of a note or whether it is not a transaction analogous to the ordinary contract. In California, the latter would seem the prevailing view annong business men. The requirement of foreclosure, the length of time a inortgage is to run, usually more than a bill of exchange, and much less than a bond, the investment character, the property features practically requiring recordation, the time required to carry out the contract, a search of title being necessarily involved, all indicate that it is a very different transaction from the simple transfer of a note or bond. Business men in California, at any rate, have accommodated themselves to this view, and in purchasing a 1nortgage either require a new mortgage or a statement froin the mortgagor as to the amount due and a waiver of defenses. ${ }^{39}$ By the California rule the mortgagor is protected froin having his general assets taken before the security is exhausted. He cannot, however, eat his cake and have it too. The note being non-negotiable is not fluid security that can be re-discounted and that will pass readily from hand to hand. The interest rate must therefore be higher, and this is one of the problems which the improved rural credit movement must solve. The suggestion has been offered that farm mortgages should be inade negotiable, and a standard security that will circulate readily. ${ }^{40}$

There is no provision in the law requiring a trust deed to be foreclosed, therefore the question has been raised by the court, and is still open, whether a note secured by a deed of trust is negotiable. ${ }^{41}$ Mortgages and deeds of trust fulfill the same function. A distinction of this kind adding to the too numerous but practically important technical distinctions between the two kinds of security, is certainly unsatisfactory. Section 3093 of the Civil Code holds expressly that a pledge of collateral security may be included in a negotiable instrument. As a matter of fact, however, most pledges and most trust deeds contain provisions for accelerated maturity, the payment of insurance, taxes, and other expenses which probably render the note non-negotiable, just as if incorporated in the note itself.

Most bonds, except government and municipals, are secured by mortgage or trust deed with elaborate conditions and restrictions.

39 Briggs v. Crawford (1912), 162 Cal. 124, 121 Pac. 381.

40 Ann. Am. Acad. Pol. \& Soc. Sciences, vol. 50, p. 189.

11 Smiley v. Watson (1913), 17 Cal. App. Dec. 697, 138 Pac. 367; Jose Realty Co. v. Pavlicevich (1913), 164 Cal. 613, 130 Pac. 15 (assumed negotiable, point not raised). 
It has accordingly been held that such bonds are non-negotiable. ${ }^{42}$ The court says:

"Both promissory notes and bonds are listed by the code as among the six classes of negotiable instruments (Civ. Code, sec. 3095), yet a promissory note loses its negotiability when conditions not certain of fulfillment are imtroduced into it. (Civ. Code, sec. 3088.) There is no essential difference between the two kinds of instruments and we see no escape from the logic of the position of appellants that a bond like a note, if dependent upon a inortgage, is subject to all equitable defenses against a holder with notice."

Is there no essential difference between the two kinds of instruments? Bills of exchange and promissory notes were developed to facilitate business transactions where certainty of payment in time and in amount were prime requisites. To accomplish these purposes, there are elaborate rules for holding the various parties liable. As against everyone except the party primarily liable, there must be demand, notice, etc., and in some cases, protest. Performance of these acts is strictly defined so that the liability incurred is definite and easily determmed. Commercial paper is usually issued for a short time to tide over the interval between the purchase of goods and their sale to the consumer. The expectation is that commercial paper will be paid promptly on maturity. All parties rely on that. These qualities of unconditional payment of a definite amount at a fixed time and place have made bills of exchange the basis of the currency system of France,a feature recently adopted by the United States. ${ }^{43}$ With paper not intended, however, as an instrument of credit, but meant to perform the function of money, like bank notes, and made payable to bearer, the complicated machinery of maturity and indorsement could be and was dispensed with. The function of bills and notes is to facilitate the exchange of commodities, but modern business has created a demand for an imstrument which shall combime the qualities of an investment with those of rapid transfer for purposes of sale or loan. Real estate is adapted for investment purposes, but it takes time to sell or to borrow money on it as a security. The maturity of a bond is usually far distant, even its ultimate payment in money is often not contemplated, but the ex-

42 Kohn v. Sacramento Elec. Gas \& Ry. Co. (June 4, 1914), 47 Cal. Dec. 690 .

${ }^{43}$ Act, Dec. 23, 1913, § 16. 
pectation is there will be a refunding and a new bond issue. The personal liability of the corporation issuing the bonds is, as a rule, comparatively valueless. The security mortgaged to the trustee is what makes the bond valuable, and a restriction to that security for the enforcement of the bond does not, in any way, impair its ability to pass freely from hand to hand. Not only is the time of payment usually far distant, but if payment is refused, and foreclosure and sale are necessary, often a receiver must be appointed, and the rights of the state, of general creditors and of stockholders are involved. A realization of the assets is therefore a slow and difficult proceeding. Everyone taking a bond knows that if there is a default, the enforcement of the liability is limited by numerous contingencies. He knows that it is not like a bill of exchange, where a simple action on the bill can be brought immediately on default. So far from there being no essential differences between the two instruments, the fact is that they have very little in common, except the fact that they are intended to pass freely from hand to hand like money so that honest possession for value is title.

The facts in the case of Kohn v. Sacramento Electric, Gas and Railway Company ${ }^{44}$ are peculiar. The Sacramento Electric, Gas and Railway Company issued bonds secured by mortgage and in the mortgage provided for the deposit of certain bonds with the California Safe Deposit and Trust Company, describing them by their serial numbers, upon a special trust for the purpose of retiring 315 outstanding bonds of a company which had been absorbed by the company issuing the bonds. These particular bonds were then feloniously abstracted by an officer of the California Safe Deposit and Trust Company and hypothecated to the plaintiff. The court does not discriminate between the two meanings of negotiability, the passing free from equities of the obligor, and the passing free from defects in the title of intermediate holders. Is the superior right which defeated the plaintiff in this case the right of the California Safe Deposit and Trust Company which held the bonds on a trust, or is the right that of the Sacramento Electric, Gas and Railway Company to set up the provisions of the mortgage as a defense to these specific bonds? The basis of the court's decision appears to be the provisions of the California Civil Code and the decisions construing those provisions. It

44 (June 4, 1914), 47 Cal. Dec. 690. 
would therefore seem that the court means to hold the bonds nonnegotiable in both senses of the word, and that neither the equities of the original obligor nor the title of intermediate transferees is cut off.

There is no inherent reason why such bonds should not pass freely from hand to hand; it is conceded to have been the intent of the parties. The provision in the inortgage imposing a special trust upon those specific bonds was intended to define the relations between the company issuing the bonds and the trustee, not to affect innocent purchasers, if the bonds should be feloniously abstracted from the trustees. A company issuing bonds never expects parties to examine at their peril the mortgage securing the issue, a document often covering several hundred pages. Such an expectation and the decree of the court sanctioning it are "at war with negotiability"-not the inherent nature of the bond. Bonds are bought usually on the reputation of the issuing company and the opinion of a bond house. All persons dealing in such securities assume that honest possession will give title, and this is the one feature of paramount and immediate importance. The conditions under which payment can eventually be enforced are entirely subordinate; practically, they cannot be known to the purchaser. It may be that some of the conditions and limitations on the enforcement of the bonds in question are unfair, but that does not alter the expectation of the parties that they should pass freely from hand to hand. If it is desirable that such conditions should be prohibited, it is a matter for the legislature. The Railroad Commission already has sufficient power to do this in the case of public utilities. ${ }^{45}$ The whole mistake has come from the attempt to apply the rules governing bills of exchange which grew up at a certain time to fulfil a mercantile need to bonds, a security growing up at a different time and for a different purpose. The distinction between the two kinds of instruments would be clearly perceived were it not for the traditional prejudices of lawyers inherited from Lord Holt that negotiability is a hateful thing, an excrescence marring the beauty and perfection of the common law system. It is the mechanical theory of law that Westminster Hall must give law to Lombard Street; that business is made for the law and not the law for business. It is, of course, true that

45 Public Utilities Act, approved Dec. 23, 1911, § 52. 
the judge cannot in all cases give effect to the desires of the commercial world. It is the function of courts to examine the agreements of business men and the usages of busmess to see whether they accord with the general welfare, and to forbid such dealings with property and such contracts as are mimical to the public good. The courts have, accordingly, prohibited perpetuities, created an equity of redemption, forbidden contracts in restraint of trade, and, in a multitude of cases, have exercised their proper authority in adjusting the interests of the individual or groups of individuals to the interest of the social whole. In this matter of the negotiability of bonds, all classes, bankers, brokers, investors, desire negotiability, and have assumed it in their transactions. If title is to be proved in each case, it creates a difficulty for the investor and a risk for the bank. The bank is less likely to lend and must charge a higher interest rate. As the ancient judges, with little or no help from legislation, worked out a theory of contracts, a theory of assignability, and a law of bills and notes to meet the expanding commercial needs, so the modern judges, in nearly every jurisdiction, have continued to meet changing conditions according to the spirit of the common law by giving effect to new forms of instruments, as created by business men. Accordingly, bonds are nearly everywhere held negotiable. In England the court expressed itself as follows:

"It is also to be remembered that the law merchant is not fixed and stereotyped; it has not yet been arrested in its growth by being moulded into a code; it is, to use the words of Cockburn C. J. in Goodrein v. Robarts [L. R. Io Ex. at p. 346], capable of being expanded and enlarged so as to meet the wants and requirements of trade in the varying circuinstances of commerce, the effect of which is that it approves and adopts from time to time those usages of merchants which are found necessary for the convenience of trade; our common law of which the law merchant is but a branch, has in the hands of the judges the same facility for adapting itself to the changing needs of the general public; principles do not alter, but old rules of applying them change, and new rules spring into existence. Thus it has been found convenient to treat securities like those in question in this action as negotiable, and the Courts of law, recognising the wisdom of the usage, have incorporated it in what is called the law merchant, and have made it part of the common law of the 
country. In my opinion the time has passed when the negotiability of bearer bonds, whether Government bonds or trading bonds, foreign or English, can be called in question in our Courts. The existence of the usage has been so often proved and its convenience is so obvious that it must be taken now to be part of the law; the very expression "bearer bond" connotes the idea of negotiability, so that the moment such bonds are issued to the public they rank themselves among the class of negotiable securities. It would be a great misfortune if it were otherwise, for it is well known that such bonds are treated in all foreign markets as deliverable from hand to hand; the attribute not only enhances their value by making them easy of transfer, but it qualifies them to serve as a kind of international currency; and it would be very odd and a great injury to our trade if these advantages were not accorded to them in this country." 46

The United States Supreme Court has expressed itself as follows :

"This species of bonds is a modern invention, intended to pass by manual delivery, and to have the qualities of negotiable paper; and their value depends mainly upon this character. Being issued by States and corporations, they are necessarily under seal. But there is nothing immoral or contrary to good policy in making them negotiable, if the necessities of commerce require that they should be so. A mere technical dogma of the courts or the common law cannot prohibit the commercial world from inventing or using any species of security not known in the last century. Usage of trade and commerce are acknowledged by courts as part of the common law, although they may have been unknown to Bracton or Blackstone. And this malleability to suit the necessities and usages of the mercantile and commercial world is one of the most valuable characteristics of the common law. When a corporation covenants to pay to bearer and gives a bond with negotiable qualities, and by this means obtams funds for the accomplishment of the useful enterprises of the day, it cannot be allowed to evade the payment by parading some obsolete judicial decision that a bond, for some technical reason, cannot be made payable to bearer.

16 Edelstein v. Schuler \& Co., [1902] 2 K. B. 144; Bechuanuland Exploration Co. v. London Trading Bank, [1898] 2 Q. B. 658. 
"That these securities are treated as negotiable by the commercial usages of the whole civilized world, and have received the sanctions of judicial recognition, not only in this court [White v. Vermont Railroad Co., 2I Howard 575], but of nearly every State in the Union, is well known and admitted." 17

This opinion of the United States Supreme Court was given in reference to municipal bonds, but the same principles apply to the bonds of private corporations. Municipal bonds are far from being unconditional promises to pay out of the general assets of the municipality. Government bonds, domestic and foreign, were the first to be recognized in England as negotiable, ${ }^{48}$ although no action at all can be brought against governments.

The statement is so often made that parties cannot attach the incidents of negotiability to any imstruments other than those recognized as negotiable by the law merchant; yet in one way or another courts accomplish the result. Sometimes, as in the case of bonds, new instruments are admitted to the class of "negotiable instruments". Writers protest that this cannot be done, ${ }^{40}$ but it is done. Sometimes the result is reached but called by another name, usually "estoppel". Accordingly, we find that where a stock certificate with an assignment in blank and power of attorney is entrusted to one who wrongfully disposes of it to a purchaser for value without notice the latter prevails. This may be called "negotiability" or "estoppel", but the name is not of so much importance in most cases, although it would seem that whenever the circumstances are so simple, so common and so easily defined, the term "negotiability" is preferable, leaving "estoppel" for those situations where the special facts of the particular case prevent one of the parties from taking advantage of the rule of law in his favor. Progress is from "estoppel" to "negotiability". It is said that a stock certificate is not a negotiable instrument because if the bona fide purchaser received it from a thief he would not prevail. This may be so, but for a long time it was a disputed question whether one who had signed a negotiable instrument was liable to a holder in due course where there had been no delivery but it

47 Mercer County v. Hackett (1863), 1 Wall. 83, at p. 95.

48 "All these instruments have been clearly framed with a view to their becoming subjects of sale, and easily transmissible from hand to hand." Att'y Gen'1 v. Bouwens (1838), 4 M. \& W. 171, at p. 190.

49 XV Law Quart. Rev. 130. See contra, XV Law Quart. Rev. 245. 
had been stolen from him. The Negotiable Instruments Law, section 16 , has settled the matter by preferring the holder in due course. It would not be surprising if stock certificates were some day treated in the same manner. At present the case of Kohn v. Sacramento Electric, Gas and Railway Company ${ }^{50}$ sanctions the distinction in National Safe Deposit Company v. Hibbs. ${ }^{5 x}$ If the officer of the Trust Company who wrongfully pledged the securities to the plaintiff had obtained them by going to the custodian of the Trust Company and representing that he was entitled to the bonds, the purchaser in good faith would have been protected, but as the dishonest officer happened to be the vicepresident of the Trust Company, and as such had access to the trust securities, the purchaser in good faith must lose. Such a distinction rests on no particular merit in the real owner or carelessness in the purchaser. It does impair the usefulness of stock certificates as collateral. It seems that the corporation by express agreement may make its certificates negotiable to the extent of cutting off equities of the corporation such as the right to assert that the stock was not fully paid up. Creditors, however, cannot be bound by such an agreement. ${ }^{22}$

County or state warrants have been held non-negotiable, ${ }^{83}$ and properly so, for a warrant while payable to order is not intended to bind the county or state unless it has been issued in every respect according to law. It is merely a means of payment and is not intended to be circulated like bank notes, although apparently when endorsed in blank it has the limited negotiability of a stock certificate. ${ }^{54}$ There seems to be no settled understanding in regard to bills of lading. They are therefore non-negotiable unless the legislature has changed the law. The curiously muddled code section in California ${ }^{55}$ has been interpreted to cut off the right of stoppage in transit.

50 (June 4, 1914), 47 Cal. Dec. 690.

51 (1913), 229. U. S. 391. This is the same distinction running through the California cases. Fowles v. Nat'1 Bank of Cal. (Apr. 11, 1914), 47 Cal. Dec. 561, 140 Pac. 271; Thompson v. Toland (1874), 48 Cal. 99; Swim v. Wilson (1891), 90 Ca1. 127, 27 Pac. 33, 13 I. R. A. 605, 25 Am. St. Rep. 110.

52 O'Dea v. Hollywood Cemetery Ass'n (1908), 154 Cal. 53, 97 Pac. 1; Perkins v. Cowles (1910), 157 Cal. 625, 108 Pac. 711, 30 L. R. A. (N. S.) 283, 137 Am. St. Rep. 158.

53 Dana v. San Francisco (1861), 19 Cal. 486; National Bank v. Herold (1888), 74 Cal. 603, 16 Pac. 507, 5 Am. St. Rep. 476.

54 Coit v. Humbert (1855), 5 Cal. 260.

55 Cal. Civ. Code, \& 2127. "All the title to the freight which the first holder of a bill of lading had when he received it, passes to every 
It has been seen that under the California doctrine almost any variation from the established conventional forms renders the instrument non-negotiable. Would it be competent in such cases to provide expressly for negotiability? In National Hardware Company v. Sherwood, ${ }^{56}$ although the note was held non-negotiable the holder recovered because he had bought the note and mortgage in reliance on the statement in a prior trust deed reading as follows: "This trust deed is given to secure the purchase price of said property, but is second and subsequent to the lien of a mortgage for the sum of three thousand dollars in favor of L. E. Jones." The recital of the consideration in the mortgage itself does not prevent the mortgagor from asserting, even as against the purchaser in good faith, that the consideration was not actually received in accordance with the oral understanding of the parties. ${ }^{57}$ Apparently the recital of consideration in a separate instrument will work the necessaty estoppel. In Flood v. Petry ${ }^{58}$ the note was for an executory consideration and contained the provision, "This note is negotiable and payable without defalcation or discount and without any relief or benefit whatever from stay, valuation, appraisement or homestead exemption laws." It will be remembered that the District Court of Appeal held the note non-negotiable on account of the executory character of the consideration. The Supreme Court, however, held that the fact that the consideration was executory and was not performed was immaterial where the plaintiff took before knowledge of the failure. The waiver of stay, valuation, appraisement or homestead exemtion laws as affecting negotiability is not discussed by the court, which places reliance on the words "This note is negotiable" as indicating the intent of the parties. In the case of Kohn v. Sacramento Electric, Gas and Railway Company ${ }^{53}$ the court says:

"Both promissory notes and bonds are listed by the code as among the six classes of negotiable instruments (Civ. Code,

subsequent indorsee thereof in good faitl and for value, in the ordinary course of business with like effect and in like manner as in the case of a bill of exchange." On the face of it this gives the indorsee no better right than the first holder, yet the court in Dodge v. Meyer, 61 Cal. 420, speaks of a bona fide purchaser and refers with approval to Newhall v. C. P. R. R. Co., 51 Cal. 350, 21 Am. Rep. 713, a case arising before the code.

56 (1913), 165 Cal. 1, 130 Pac. 881.

57 Briggs v. Crawford (1912), 162 Cal. 124, 121 Pac. 381; Smiley v. Watson (1913), $17 \mathrm{Cal}$. App. Dec. 697, $138 \mathrm{Pac} .367$.

58 (1913), 165 Cal. 309, 132 Pac. 256.

59 (June 4, 1914), 47 Cal. Dec. 690. 
sec. 3095), yet a promissory note loses its negotiability when conditions not certain of fulfilment are introduced into it. (Civ. Code, sec. 3088.) There is no essential difference between the two kinds of instruments and we see no escape from the logic of the position of appellants that a bond like a note, if dependent upon a mortgage, is subject to all equitable defenses against a holder with notice."

Does this mean that if the intent had been expressed in the instrument it would have prevailed? If by express agreement the parties can make an instrument negotiable that would otherwise be non-negotiable, the effect of the California decisions will be simply to add in the future four words-"This instrument is negotiable"- to every instrument intended as such. There has not, however, been a sufficient consideration of this matter by the California courts to make it safe to predict what the decision would be on negotiability by contract. Irrigation bonds are by statute declared to be negotiable. ${ }^{60}$ There would seem to be no reason why the statute should not prevail.

Imperfect codification, a rigid adherence to formal rules and a firm refusal to look at business conditions have brought about a remarkable result in California. No business man would have any doubt as to what the law ought to be in regard to the instruments above discussed. No lawyer looking at the principle of the thing would have any doubt in the great majority of cases. The courts in England and in the United States generally have decided, as a rule, in favor of negotiability. In California, following the minority view, the usual provisions inserted in negotiable instruments throughout the country and frequently in California render the paper non-negotiable. Most notes drawn by business men are, contrary to the belief of the parties, non-negotiable. A California lawyer knows only this, - that certain additions to the ancient conventional forms will surely render the instrument non-negotiable. Anything else will raise a doubt. New and unnecessary distinctions present themselves, such as the non-negotiability of a note secured by mortgage and the doubt as to a note secured by a deed of trust. The negotiability of bonds assumed by every business man and on the faith of which every bank and broker and stock exchange have transacted business has been involved in doubt for years and, subject to rehearing, has been decided

60 Stowell v. Rialto Irr. Dist. (1909), 155 Cal. 215, 100 Pac. 248. 
contrary to the weight of authority in the rest of the common law world.

It is not contended that the decision in Kohn v. Sacramento Electric, Gas and Railway Company ${ }^{61}$ is wrong. Rigid codification and narrow interpretation by former judges have brought about a situation where the court must either overrule the principles of well established cases or disappoint the expectations of the public. To overrule well established precedents is an undesirable shock to the security of our entire legal systen. The atteinpt to work out justice in particular cases by subtle distinctions on unessential grounds creates still more uncertainty for the future. It is not that the decision is bad law but that the law is bad. The decision is wrong on primciple and wrong as a decision on the present law in common law jurisdictions; it can be sustained only on the theory that with the adoption of the codes further progress in the law became impossible and five centuries of continuous common law growth came to an end. Codification is certainly a misfortune when it prevents the court from working out the rule that will fit existing conditions, as has been done in other branches of the law, notably in the law of waters.

"Even if at common law or under the civil law it was a part of the usufructuary right of the riparian owner to have the water flow by for no purpose other than to afford him pleasure in its prospect, such is not the rule of decision in this state. The lower claimant inust show dainage to justify a court of equity in restraining an upper claimant from his beneficial use of the water. The fair apportionment and economic use of the waters of this state are of the utmost importance to its development and well-being. The problems presented never came within the purview of the coinmon law. They have of necessity, therefore, and must continue to be solved by this court as cases of first impression, and, as in the past, 'so in the future, if a rule of decision at common law shall be found unfitted to the radically changed conditions existing in this state, so that its application will work wrong and hardship rather than betterment and good, this court will refuse to approve and follow the doctrine." ${ }^{62}$

61 (June 4, 1914), 47 Cal. Dec. 690.

${ }^{62}$ San Joaquin etc. Co. v. Fresno Flume Co. (1910), 158 Cal. 626, 112 Pac. 182. 
"The Negotiable Instruments Law" now adopted in some fortyseven states is suggested as a remedy. From the cry of despair which one of its distinguished proponents, the Hon. Amasa M. Eaton, is uttering in the legal periodicals the act is not accomplishing all that was hoped for. ${ }^{63}$ Nevertheless, it would be a great improvement if adopted in California. It is intrinsically a far better codification-to say nothing of the advantages of uniformity. The last two California legislatures have passed a "Negotiable Instruments Law", but each time it has been vetoed by the Governor apparently without any attempt to compare the merits of the two codifications. It does seem, however, as if the "Negotiable Instruments Law" itself is lacking in some respects. It appears to be too much a codification of the law of bills and notes and not of negotiable instruments. While it appears that bonds are negotiable ${ }^{64}$ the law is far froin specific. In Strickland v. National Salt Coinpanyes a certificate somewhat anomalous in forn was issued. It contaimed an agreement to keep free from encumbrance property on which the value of collateral pledged for the security of the certificate depended. The New Jersey court held the certificate non-negotiable. The federal court reached an opposite conclusion. ${ }^{68}$ The question was suggested but not passed on whether the adoption of the "Negotiable Instruments Law" made it impossible to create new forms of negotiable instruments. Mr. Eaton says it does not; that the act itself provides for new forms. The section relied on, however, is not very clearly worded. ${ }^{67}$ It might be considered to mean the law merchant as it was when taken over by the common law courts and developed by Lord Mansfield.

It is submitted that for the success of the "Negotiable Instruments Law" certain principles should be recoguized:

I. The act should specifically provide for the negotiability of all instruments which business men now assume to be negotiable and where no public interest is violated. The law should further contain within itself the principle of expansion to growing needs.

6378 Cent. Law Jour. 130; 62 Univ. of Pa. Law Rev. 407; 23 Yale Law Jour. 293; 12 Mich. Law Rev. 89.

64 Brannan's Negotiable Instruments Law, p. 3.

65 (1911), 79 N. J. Eq. 182, 81 At1. 828.

${ }^{66}$ National Salt Co. v. Ingraham (1906), 143 Fed. 805 (defense of illegality of consideration not allowed against a purchaser without notice).

${ }_{67}$ "In any case not provided for in this act the rules of the law merchant shall govern." The Negotiable Instruments Law, § 196. 
2. The work of no code commission should be considered final, but periodically the instrument should be tuned up to accord with changing conditions. The imperfect generalizations should be corrected in the light of wider experience, and where there are conflicting interpretations the rule should be made uniform.

3. To secure uniform interpretations a complete annotated edition of the "Negotiable Instruments Law" should be published with supplenental annotations at frequent intervals and every device employed to make it easy for judges and lawyers to find the interpretation of each section. ${ }^{68}$ It may then become a habit when a question involving negotiable instruments arises to consult the "Negotiable Instruments Law" first.

If this is done, and if the "Negotiable Instruments Law" can be passed in California, the California courts will have an opportunity to make the law on this subject responsive to the "felt needs" of the community and to carry out the real principle of the common law, which is to recognize the relations business men create, not make them.

A. M. KIDD.

Berkeley, California.

ss Brannan's Negotiable Instruments Law furnishes an excellent foundation. 